\title{
Multiple Borrowing and Living Standard: A Study in Bangladesh
}

\author{
Md. Shahidul Islam \\ Department of Economics, Southeast University, Dhaka, Bangladesh \\ Email address: \\ yesiampanna@gmail.com

\section{To cite this article:} \\ Md. Shahidul Islam. Multiple Borrowing and Living Standard: A Study in Bangladesh. International Journal of Economic Behavior and \\ Organization. Vol. 7, No. 1, 2019, pp. 19-27. doi: 10.11648/j.ijebo.20190701.14
}

Received: April 5, 2019; Accepted: May 23, 2019; Published: June 10, 2019

\begin{abstract}
The people in Bangladesh have no access to formal lending institutions. Consequently, they borrow from non government organizations (NGOs) where they do not need to show any collateral and for different reasons they borrow from more than one NGO. This study examines the impact of multiple borrowing on living standard of the borrowers and tries to find out the determinants of borrowers' income. Result shows that there is no significant difference in gross income between the groups of borrowers borrowing from single source and borrowing from multiple sources. But, in case of living expenses, savings and amount of non-land assets, there is significant difference between the groups. Borrowers who borrow from single source can spend more for quality life than those who borrow from multiple sources. Since the borrowers who borrow from multiple sources are to pay a larger amount of their income in their installments and they are to bear larger transaction cost, they can save less in spite of making less expense on quality of life. The borrowers borrowing from single source have significantly higher amount of savings and non-land assets than those who borrow from multiple sources. Policy makers should make policies in a way so that that the borrowers can get sufficient amount of loan from one source and they are encouraged to avoid loan from multiple sources which impose higher level of loan transaction costs $\&$ repayment burden.
\end{abstract}

Keywords: Multiple Borrowing, Living Standard, Income, Living Expenses

\section{Introduction}

No poverty and zero hunger are two goals of sustainable development goals (SDGs) set by the United Nations General Assembly in 2015. It is important to ensure the access of the rural poor to the capital which includes financial, social, natural and physical capital in order to achieve sustainable and developed living-standard of the rural poor. [1] The poor in developing countries have a lack of access to formal financial institutions. [2-4] In other words, conventional baking system has failed to provide financial services to the rural poor due to collateral requirements, higher transaction cost and lack of information. [5-6] Among the poor, women have less access to the formal financial market than men. [7] Bangladesh is called the motherland of microcredit program which requires no collateral for loan. It has emerged as one of the crucial weapons to alleviate poverty. [8-12] In Bangladesh, microcredit support has been being provided by the Government of Bangladesh (GoB) and non-governmental organizations (NGOs) to the poor (focusing on the women) to improve their living standards by creating greater opportunities for income-generating activities. [2] Still, poverty reduction remains the most daunting challenge for Bangladesh. 23.2\% people of Bangladesh live under poverty line. [13] They cannot earn enough money to meet basic needs like food, housing, clothing, education and health care.

Nowadays, collateral free microcredit access is available to the poor in Bangladesh and borrowers borrow from different microcredit institutions. Since rural poor women in Bangladesh have limited access to the productive resources as compared to their male counterparts due to existing patriarchal norms of the society most of the prominent microcredit institutions give emphasis to provide credit facilities to the women who make up half the population. [14-17] In most cases, women act as a medium of getting loans from microcredit institutions and the heads of households use the credits. They use microcredit in both unproductive way like marriage, to pay for dowry etc and productive way like small scale poultry or cattle rearing activities, cultivation of land etc. [18] But some problems are 
being created; borrowers don't have land and other resources in order to utilize their borrowed loan. Possession of land is considered as a crucial factor for permanent income and consumption of rural households. The more the land possessed by households, the higher the advantageous position of the households in terms of negotiation, investment, production, and risk-bearings as compared to the households with no land or small pieces of land. In addition, quality of rural infrastructural facilities like roads, markets, cold storage etc. plays vital role to increase the rural people's participation in economic activities. [19] The poor people have low level of education and skill to pursue income generating activities. [20] Amount of microcredit from one NGO is not adequate to use properly. Lenders grant borrowers only one week after which borrowers are to start paying back their installments. [21] Consequently, they are to borrow from more than one microcredit institution. In some cases they can't cope with the required management of the loans, they become poorer and unable to pay back their installments. In recent years, concerns have been raised about the effectiveness of borrowing from multiple sources and borrowing from multiple sources, by and large, is considered as one of the evidences of failure.

Globally, there are a few studies on impact of borrowing from multiple sources on living standard of rural borrowers. Of them, some studies indicate that multiple borrowing has a positive effect on living standard while others show that it leads to over indebtedness and consequently default on loan trap. Prevalence of multiple borrowing at Iringa in Tanzania is very high- over $70 \%$ of the microfinance clients have at least two loans from different microfinance institutions (MFIs) at the same time, and they face serious problems in loan repayment because of multiple pending loans. [22] Almost $71 \%$ microcredit borrowers are somehow involved in multiple borrowing of them about $69 \%$ admit of being late in their loan repayments. They are facing more trouble in timely repayments. [23] About 91\% respondents among microfinance networks and other industry players report that their sector is experiencing multiple borrowing while $73 \%$ report evidence of client over-indebtedness. $70 \%$ of respondents report that there is a correlation between multiple borrowing and over-indebtedness. [24] Multiple borrowing causes over-indebtedness, if this overindebtedness is not checked, multiple borrowers are more likely to experience more hardships instead of leading better lives. [25] Clients with loans from multiple sources at the same time are found to be more likely to default than others. [26] Multiple borrowing increases irregularity of loan repayment and it increases over-indebtedness. [27-28]

On the contrary, this is evidence from a study that multiple borrowers have equal or better repayment records than their single borrowing peers in the same villages. [29] Repayment performance does not worsen in more competitive locations for most of the MFIs which suggests good risk management, screening and monitoring by those MFIs. Better repayment of loans indicates better livelihood of the borrowers. [29] There is no evidence of growing indebtedness for the overlapping households. Rather, self-employment is higher for the overlapping households. In addition, overlapping households are better off in total assets, net worth, savings, consumption, employment days and non-food expenditures, than the non-overlapping households. [30] There was no negative relationship between multiple borrowing and repayment performance. [31] Though overlapping has not contributed to over-indebtedness for any group of overlapping households, but there are areas of concern. First, overlapping households with five or more memberships have lesser growth in net assets than other groups. These households use a large part of their loans for lumpy expenditures and repayment of previous loans. Second, households with exposure to covariate shocks are more likely to be over-indebted because of their negative growth rate of net assets. [32]

It is the fact from the reviewed literature that studies on multiple borrowing and its impact on living standard of rural borrowers have not been well studied in the context of Bangladesh which raises demand for an attempt to bridge this knowledge gap. This study aims to: (1) examine the impact of multiple borrowing on living standard of rural borrowers, (2) determine the determinants of income of the borrowers and, (3) recommend appropriate policies in this regard.

\section{Conceptual Framework}

Theory of utility states that budget of consumers increases provided that income of the consumers increases, which ultimately helps them to purchase higher amount of goods and services to maximize their utility. It is the fact that sampled borrowers' households under this study are poor having low level of income. Access of the poor to microcredit program would help them to be engaged in income generating activities. Opportunity of borrowing from multiple sources will encourage the borrowers to borrow a big amount accumulated from different institutions at a time so that the amount can be invested to start a new business. The business or income generating activity is expected to ameliorate their financial condition by increasing income. Increased income will assist them to have higher level of expenditure resulting in higher living-standard for them. This economic behavior is consistent with the theory of utility maximization.

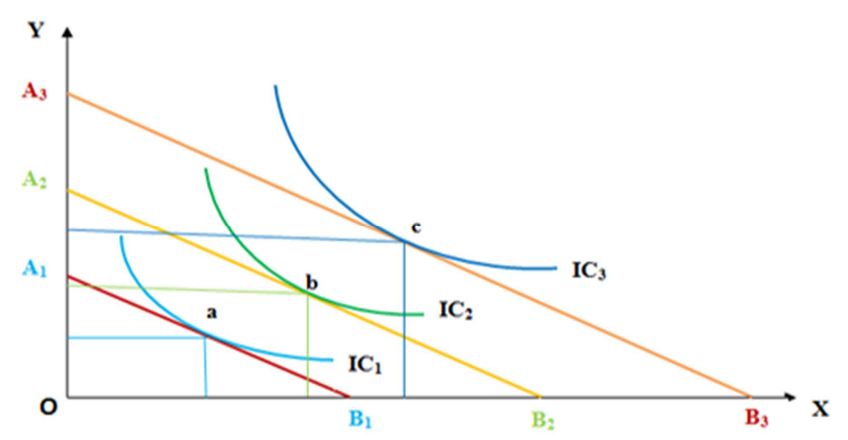

Figure 1. Graphical Presentation of Utility Theory. 
This study has tried to examine whether the multiple borrowers are able to move from point a to point c comparing with the borrowers borrowing from single source who are expectedto move from point $\mathrm{a}$ to point $\mathrm{b}$ after receiving microcredit (figure 1).

\section{Methodology of the Study}

The methodology adopted for this study is exhibited as follows:

\subsection{Study Area}

There are 64 districts in Bangladesh from which Bogura district has been selected by using simple random sampling method.

\subsection{Sample Size Estimation}

The followingmethod of statistical estimation of sample size has been adopted in this study: [33]

$$
S=X 2 N P(1-P) \div d 2(N-1)+X 2 P(1-P)
$$

$S=$ required sample size.

$X^{2}=$ the table value of chi-square for 1 degree of freedom at the desired confidence level.

$N=$ the population size.

$P=$ the variability in population (assumed to be. 50 since this would show maximum variability, provide the maximum sample size).

$D=$ the degree of accuracy expressed as a proportion.

In this study, the confidence level has been considered as 95 percent and 5 percent is acceptable error. Te estimated sample size is 384 but at the conclusive stage the sample size has been made 400 with a view to avoiding any difficulty at the time of data analysis and interpretation.

\subsection{Sampling Procedure and Data Collection}

It can be noted that data have been collected from borrowers who borrow from various non-government organizations (NGOs) rather than formal banks (as the poor do not have access to). NGOs provide microcredit to the poor which requires no collateral. In Bogura there are 11 thanas. 2 thanas have been selected by simple random sampling. One union from each of the thanas has been selected randomly.
Then names of villages of the unions, where more than one microfinance institution work, have been collected. Randomly 5 villages from each union have been selected. Finally convenient sampling has been used to select the borrowers.

For convenient comparison among data, samples have been collected from borrowers who borrow from single source, two sources and more than two sources. From a pilot study in a village of study area, it is found that $52 \%$ borrowers borrow from single source, $30 \%$ borrowers borrow from two sources and 18\% borrowers borrow from more than two sources. To be consistent with sample size, 208data set have been collected from borrowers who borrow from single source, 120 data set have been collected from borrowers who borrow from two sources and 72data set have been collected from borrowers who borrow from more than two sources. Structured questionnaires have been used for collecting the data by interviewing the clients.

\subsection{Research Method}

To see whether there is a statistically significant difference in income, living expenses, savings, amount of land and nonland assets of borrowers borrowing from different number of sources, ANOVA has been carried out. In addition to it, to find out which type of borrowers is to what extent different from other types, Tukey's post-hoc tests have been adopted. It can be noted that Tukey's post-hoc tests are like a series of ttests and are more stringent than the regular t-tests.

Econometric analysis has been carried out to find out determinants of income of borrowers.

To find out the determinants of income of the borrowers borrowing from different number of sources, the following regression model has been run:

$$
Y=\beta 0+\beta 1 A+\beta 2 E+\beta 3 L+\beta 4 B S+u
$$

Here, $\mathrm{Y}=$ gross income of borrowers.

$\mathrm{A}=$ age of borrowers.

$\mathrm{E}=$ education of borrowers (Categorical variable).

$\mathrm{L}=$ amount of land in decimal owned by the borrowers.

$\mathrm{BS}=$ number of borrowing sources (Categorical variable).

$\beta_{1}, \ldots \ldots \ldots \beta_{4}=$ coefficients, $\beta_{0}=$ Constant, $u=$ error term.

The table 1 shows how the values of the categorical variables have been handled.

Table 1. Categorical variables.

\begin{tabular}{lllll}
\hline \multirow{2}{*}{ Variables } & \multirow{2}{*}{ Frequency } & Parameter coding & (2) \\
\cline { 3 - 5 } & & & $\mathbf{( 1 )}$ & .000 \\
Source (s) of borrowing & Single source & 208 & .000 & .000 \\
& Two sources & 120 & 1.000 & 1.000 \\
\multirow{2}{*}{ Borrowers' education } & More than two sources & 72 & .000 & .000 \\
\hline
\end{tabular}

Kolmogorov-Smirnov test and Shapiro-Wilk test have been used to check normality in data. Values of Tolerance and the Variance Inflating Factor have been used to check multicollinearity problem among independent variables.
Scatter plot of standardized predicted value of the dependant variable (ZPRED) and standardized residual of the model (ZRED) has been used to check heteroscedasticity problem in data. 


\section{Findings and Discussion}

\subsection{Sources of Borrowing}

Borrowers in the study area borrow from 8 different lending organizations. Table 2 shows the name of organizations and the ratio of borrowers borrowing from the different organizations.

Table 2. Proportion of borrowers borrowing from various organizations.

\begin{tabular}{|c|c|c|}
\hline SI. No. & Organizations & Borrowers \\
\hline 1 & Association for Social Advancement (ASA) & $64 \%$ \\
\hline 2 & Grameen Bank & $35 \%$ \\
\hline 3 & Shomaj Kallan Shongstha (SKS) & $20 \%$ \\
\hline 4 & Basic Unit for Resources and Opportunities (BURO) & $19 \%$ \\
\hline 5 & United Development Initiatives for Programmed Actions (UDDIPAN) & $15 \%$ \\
\hline 6 & Bangladesh Rural Advancement Committee (BRAC) & $7 \%$ \\
\hline 7 & Rainbow Nari O Shishu Kallyan Foundation & $6 \%$ \\
\hline
\end{tabular}

\subsection{Average Annual Income of Borrowers}

Table 3 shows that the borrowers who borrow from more than two sources earn Tk. 1,72,403 yearly which is followed by the borrowers borrowing from two sources (Tk. 1,64,783). The borrowers who borrow from single source earn Tk. $1,45,808$ yearly. It is seen that the higher the number of borrowing sources, the higher the income. In addition, to see whether there is a significant difference in income of borrowers borrowing from different number of sources, ANOVA has been carried out. The result is statistically insignificant and it refers that there is no statistically significant difference in income of borrowers borrowing from different number of sources. In other words, there is no statistically significant effect of number of borrowing sources on income of borrowers. ( $\mathrm{F}=1.408, \mathrm{p}=.246)$.

Table 3. Average annual income of borrowers.

\begin{tabular}{|c|c|c|c|c|c|c|c|}
\hline \multirow{2}{*}{ Sources of borrowing } & \multirow{2}{*}{ Income (Tk.) } & \multicolumn{6}{|l|}{ ANOVA (Income) } \\
\hline & & & Sum of Squares & df & Mean Square & $\mathbf{F}$ & Sig. \\
\hline Single & $1,45,808$ & Between Groups & $5.020 \mathrm{E} 10$ & 2 & $2.510 \mathrm{E} 10$ & 1.408 & .246 \\
\hline Two & $1,64,783$ & Within Groups & $7.078 \mathrm{E} 12$ & 397 & $1.783 \mathrm{E} 10$ & & \\
\hline
\end{tabular}

To find out which means are to what extent different from other means, Tukey's post-hoc tests, which are like a series of ttests and are more stringent than the regular t-tests, have been considered.

The Table 4 shows mean differences among the borrowers borrowing from different number of sources. These mean differences are statistically insignificant.

Table 4. Tukey's Post-hoc tests (Total income in Tk.).

\begin{tabular}{|c|c|c|c|c|c|c|}
\hline \multirow{2}{*}{$\begin{array}{l}\text { (I) No. of sources of } \\
\text { borrowing }\end{array}$} & \multirow{2}{*}{$\begin{array}{l}\text { (J) No. of sources of } \\
\text { borrowing }\end{array}$} & \multirow{2}{*}{ Mean Difference (I-J) } & \multirow{2}{*}{ Std. Error } & \multirow{2}{*}{ Sig. } & \multicolumn{2}{|c|}{ 95\% Confidence Interval } \\
\hline & & & & & Lower Bound & Upper Bound \\
\hline \multirow{2}{*}{ Single } & Two & -18975.641 & $1.531 \mathrm{E} 4$ & .430 & -54983.92 & 17032.64 \\
\hline & More than two & -26595.113 & $1.826 \mathrm{E} 4$ & .313 & -69545.67 & 16355.44 \\
\hline \multirow{2}{*}{ Two } & Single & 18975.641 & $1.531 \mathrm{E} 4$ & .430 & -17032.64 & 54983.92 \\
\hline & More than two & -7619.472 & $1.990 \mathrm{E} 4$ & .922 & -54444.87 & 39205.92 \\
\hline More than two & Single & 26595.113 & $1.826 \mathrm{E} 4$ & .313 & -16355.44 & 69545.67 \\
\hline
\end{tabular}

This study indicates that there are no significant differences in income among the borrowers borrowing from single, two and more than two sources.

\subsection{Average Annual Living Expenses of Borrowers}

Table 5 shows that the borrowers who borrow from single source spend Tk. 56,186 yearly for their living which is followed by the borrowers borrowing from two sources (Tk. $50,454)$. The borrowers who borrow from more than two sources spend Tk. 45,958 yearly. Data on various items of living expenses show that almost in all cases, single source borrowers spend more than those who borrow from two and more than two sources. It is seen that the higher the number of borrowing sources, the lower the expenditure for quality life. It should be mentioned that living expenses does not include expenditure for repayment of loans in their installments. 
Table 5. Average annual living expenses of borrowers.

\begin{tabular}{llllll}
\hline $\begin{array}{l}\text { No. of sources of } \\
\text { borrowing }\end{array}$ & $\begin{array}{l}\text { Living Expenses } \\
\text { (Tk.) }\end{array}$ & $\begin{array}{l}\text { Expenses on } \\
\text { Food }\end{array}$ & $\begin{array}{l}\text { Expenses on } \\
\text { Education }\end{array}$ & $\begin{array}{l}\text { Expenses on } \\
\text { Clothing }\end{array}$ & $\begin{array}{l}\text { Expenses on } \\
\text { Medicine }\end{array}$ \\
\hline Single & 56,186 & 28,103 & 5,936 & 8,584 & $\begin{array}{l}\text { Expenses on } \\
\text { Others }\end{array}$ \\
Two & 50,454 & 25,008 & 5,740 & 8,573 \\
More than two & 45,958 & 22,402 & 5,551 & 7,604 & 3,062 \\
\hline
\end{tabular}

ANOVA result is statistically significant (Table 6) and it refers that there is a statistically significant difference in living expenses of borrowers borrowing from different number of sources. In other words, there is a significant effect of number of borrowing sources on living expenses of borrowers. $(\mathrm{F}=6.552, \mathrm{p}=.002)$.

Table 6. ANOVA (Living expenses).

\begin{tabular}{lllll}
\hline Living Expenses (Tk.) & Sum of Squares & df & Mean Square & F \\
\hline Between Groups & $6.402 \mathrm{E} 9$ & 2 & $3.201 \mathrm{E} 9$ & 6.552 \\
Within Groups & $1.940 \mathrm{E} 11$ & 397 & $4.886 \mathrm{E} 8$ \\
Total & $2.004 \mathrm{E} 11$ & 399 & & .002 \\
\hline
\end{tabular}

Tukey's post-hoc tests (Table 7) reveal that there is a significant difference in living expenses only between the borrowers borrowing from single source and those borrowing from more than two sources. There is no significant difference in living expenses between the borrowers borrowing from single source and those borrowing from two sources.

Table 7. Tukey's Post-hoc tests (Living expenses in Tk.).

\begin{tabular}{llllll}
\hline $\begin{array}{l}\text { (I) No. of sources of } \\
\text { borrowing }\end{array}$ & $\begin{array}{l}\text { (J) No. of sources of } \\
\text { borrowing }\end{array}$ & $\begin{array}{l}\text { Mean Difference } \\
\text { (I-J) }\end{array}$ & Std. Error & Sig. & \multicolumn{2}{c}{ 95\% Confidence Interval } \\
\hline \multirow{2}{*}{ Single } & Two & 5731.410 & 2533.893 & .062 & -229.67 \\
& More than two & $10227.244^{*}$ & 3022.419 & .002 & 3116.89 \\
\multirow{2}{*}{ Two } & Single & -5731.410 & 2533.893 & .062 & -11692.49 \\
& More than two & 4495.833 & 3295.091 & .361 & -3255.99 \\
More than two & Single & $-10227.244^{*}$ & 3022.419 & .002 & -17337.60 \\
& Two & -4495.833 & 3295.091 & .361 & -12247.66 \\
\hline
\end{tabular}

*. The mean difference is significant at the 0.05 level.

\subsection{Average Annual Savings of Borrowers}

Table 8 shows that the borrowers who borrow from single source have the highest amount of savings (Tk. 29,980) yearly which is followed by the borrowers borrowing from two sources (Tk. 18,080). The borrowers who borrow from more than two sources have yearly savings worth Tk. 11,100. It is seen that the higher the number of borrowing sources, the lower the savings. It should be mentioned that though the borrowers who borrow from more than two sources earn the highest amount, they have the least amount of savings due to the fact that they are to repay the highest amount in installments. ANOVA result is statistically significant (Table 8) and it refers that there is a statistically significant difference in savings of borrowers borrowing from different number of sources. In other words, there is a significant effect of number of borrowing sources on savings of borrowers. $(\mathrm{F}=2.673, \mathrm{p}=.070)$.

Table 8. Average annual savings of borrowers.

\begin{tabular}{lllllll}
\hline \multirow{2}{*}{ Sources of borrowing } & \multirow{2}{*}{ Savings (Tk.) } & ANOVA (Savings) & & & & \\
\cline { 3 - 6 } & & & Sum of Squares & df & Mean Square & F \\
\hline Single & 29,980 & Between Groups & $5.809 \mathrm{E} 9$ & 2 & $2.905 \mathrm{E} 9$ & 2.673 \\
Two & 18,080 & Within Groups & $4.313 \mathrm{E} 11$ & 397 & $1.086 \mathrm{E} 9$ & .070 \\
More than two & 11,100 & Total & $4.371 \mathrm{E} 11$ & 399 & & \\
\hline
\end{tabular}

Tukey's post-hoc tests (Table 9) indicate that there is a significant difference in savings only between the borrowers borrowing from single source and those from more than two sources. There is no significant difference in savings between the borrowers borrowing from single source and those borrowing from two sources.

Table 9. Tukey's Post-hoc tests (Savings in Tk.).

\begin{tabular}{llllll}
\hline $\begin{array}{l}\text { (I) No. of sources of } \\
\text { borrowing }\end{array}$ & $\begin{array}{l}\text { (J) No. of sources of } \\
\text { borrowing }\end{array}$ & Mean Difference (I-J) & \multirow{2}{*}{ Std. Error } & \multirow{2}{*}{ Sig. } & \multicolumn{2}{c}{ 95\% Confidence Interval } & Lower Bound & Upper Bound \\
\hline \multirow{2}{*}{ Single } & Two & 11900.385 & 3778.551 & .258 & -2938.80 \\
& More than two & $18880.385^{*}$ & 4507.043 & .049 & -1162.60 \\
\hline
\end{tabular}




\begin{tabular}{lllllll}
\hline $\begin{array}{llllll}\text { (I) No. of sources of } \\
\text { borrowing }\end{array}$ & $\begin{array}{l}\text { (J) No. of sources of } \\
\text { borrowing }\end{array}$ & \multirow{2}{*}{ Mean Difference (I-J) } & \multirow{2}{*}{ Std. Error } & \multirow{2}{*}{ Sig. } & \multicolumn{2}{l}{ 95\% Confidence Interval } \\
\hline \multirow{2}{*}{ Two } & Single & -11900.385 & 3778.551 & .258 & -14839.56 & 2938.80 \\
& More than two & 6980.000 & 4913.652 & .758 & -8069.55 & 15049.55 \\
\multirow{2}{*}{ More than two } & Single & $-18880.385^{*}$ & 4507.043 & .049 & -20043.37 & 1162.60 \\
& Two & -6980.000 & 4913.652 & .758 & -15049.55 & 8069.55 \\
\hline
\end{tabular}

*. The mean difference is significant at the 0.05 level.

\subsection{Average Amount of Land}

From table 10, it is seen that all types of borrowers borrowing from different number of sources have almost same amount of land. There is no difference in amount of land owned by the borrowers borrowing from different number of sources.

Table 10. Average amount of land.

\begin{tabular}{lllllll}
\hline \multirow{2}{*}{ Sources of borrowing } & \multirow{2}{*}{ Land (Decimal) } & ANOVA (Land) & & & \\
\cline { 3 - 6 } & & & Sum of Squares & df & Mean Square & F \\
\hline Single & 29,980 & Between Groups & 340.48 & 2 & 170.240 & .264 \\
Two & 18,080 & Within Groups & 256225.44 & 397 & 645.404 & .768 \\
More than two & 11,100 & Total & 256565.92 & 399 & & \\
\hline
\end{tabular}

ANOVA shows statistically insignificant result (Table 10) and it refers that there is no statistically significant difference in amount of land owned by the borrowers borrowing from different number of sources. In other words, there is no significant effect of number of borrowing sources on amount of land ownership of borrowers. $(F=0.264, p=.768)$.

The following table 11 indicates that there are no significant differences in amount of land among the borrowers borrowing from single, two and more than two sources.

Table 11. Tukey's Post-hoc tests (Land in decimal).

\begin{tabular}{|c|c|c|c|c|c|c|}
\hline \multirow{2}{*}{$\begin{array}{l}\text { (I) No. of sources of } \\
\text { borrowing }\end{array}$} & \multirow{2}{*}{$\begin{array}{l}(\mathrm{J}) \text { No. of sources of } \\
\text { borrowing }\end{array}$} & \multirow{2}{*}{ Mean Difference (I-J) } & \multirow{2}{*}{ Std. Error } & \multirow{2}{*}{ Sig. } & \multicolumn{2}{|c|}{ 95\% Confidence Interval } \\
\hline & & & & & Lower Bound & Upper Bound \\
\hline \multirow{2}{*}{ Single } & Two & 1.23359 & 2.91226 & .906 & -5.6176 & 8.0848 \\
\hline & More than two & -1.49947 & 3.47374 & .902 & -9.6716 & 6.6726 \\
\hline \multirow{2}{*}{ Two } & Single & -1.23359 & 2.91226 & .906 & -8.0848 & 5.6176 \\
\hline & More than two & -2.73306 & 3.78712 & .751 & -11.6424 & 6.1763 \\
\hline \multirow{2}{*}{ More than two } & Single & 1.49947 & 3.47374 & .902 & -6.6726 & 9.6716 \\
\hline & Two & 2.73306 & 3.78712 & .751 & -6.1763 & 11.6424 \\
\hline
\end{tabular}

\subsection{Average Non-land Assets of Borrowers}

Table 12 shows that the borrowers who borrow from single source have highest amount of non-land assets (furniture, tv, refrigerator etc. excluding gold ornaments) worth Tk. 74,208 which is followed by the borrowers borrowing from two sources (Tk. 71,236). The borrowers who borrow from more than two sources have non-land assets worth Tk. 57,360. It is seen that the higher the number of borrowing sources, the lower the amount of non-land assets. ANOVA shows statistically significant result and it refers that there is a statistically significant difference in amount of non-land assets of borrowers borrowing from different number of sources. In other words, there is a significant effect of number of borrowing sources on non-land assets of borrowers. $(\mathrm{F}=3.275, \mathrm{p}=.039)$.

Table 12. Average non-land assets of borrowers.

\begin{tabular}{|c|c|c|c|c|c|c|c|}
\hline \multirow{2}{*}{ Sources of borrowing } & \multirow{2}{*}{ Non-Land Assets (Tk.) } & \multicolumn{6}{|c|}{ ANOVA (Non-Land Assets in TK.) } \\
\hline & & & Sum of Squares & df & Mean Square & $\mathbf{F}$ & Sig. \\
\hline Single & 74,208 & Between Groups & $2.511 \mathrm{E} 10$ & 2 & $1.256 \mathrm{E} 10$ & 3.275 & .039 \\
\hline Two & 71,236 & Within Groups & $1.522 \mathrm{E} 12$ & 397 & $3.833 \mathrm{E} 9$ & & \\
\hline More than two & 57,360 & Total & $1.547 \mathrm{E} 12$ & 399 & & & \\
\hline
\end{tabular}

Tukey's post-hoc tests (Table 13) show that there is a significant difference in non-land assets only between the borrowers borrowing from single source and those from more than two sources. There is no significant difference in non-land assets between the borrowers borrowing from single sources and those from two sources. 
Table 13. Tukey's Post-hoc tests (non-land assets in Tk.).

\begin{tabular}{llllll}
\hline $\begin{array}{l}\text { (I) No. of sources of } \\
\text { borrowing }\end{array}$ & $\begin{array}{l}(\mathbf{J}) \text { No. of sources of } \\
\text { borrowing }\end{array}$ & \multirow{2}{*}{ Mean Difference (I-J) } & \multirow{2}{*}{ Std. Error } & \multirow{2}{*}{ Sig. } & \multicolumn{2}{c}{ 95\% Confidence Interval } & Lower Bound & Upper Bound & 6040.46 \\
\hline \multirow{2}{*}{ Single } & Two & -13875.534 & 8465.753 & .230 & -33791.53 \\
& More than two & $16847.756^{*}$ & 7097.397 & .047 & 150.87 \\
\multirow{2}{*}{ Two } & Single & 13875.534 & 8465.753 & .230 & -6040.46 \\
& More than two & -2972.222 & 9229.501 & .944 & 18740.52 \\
\multirow{2}{*}{ More than two } & Single & $-16847.756^{*}$ & 7097.397 & .047 & -33544.65 \\
& Two & 2972.222 & 9229.501 & .944 & 24684.97 \\
\hline
\end{tabular}

*. The mean difference is significant at the 0.05 level.

\subsection{Determinants of Income}

Table 14 shows that Kolmogorov-Smirnov test and Shapiro-Wilk test are insignificant at 21\% and 59.1\% level respectively which accept the null hypothesis of normality in data. It means that the data are normally distributed.

Table 14. Normality test.

\begin{tabular}{lllllll}
\hline & \multicolumn{4}{l}{ Kolmogorov-Smirnov } & \multicolumn{3}{l}{ Shapiro-Wilk } \\
\cline { 2 - 7 } & Statistic & df & Sig. & Statistic & df & Sig. \\
\hline Total Income & .303 & 208 & .210 & .559 & 208 & .591 \\
\hline
\end{tabular}

Table 15 shows that the values of VIF are less than 3 and the values of tolerance are more than. 20 which reveal the fact that there is no multicollinearity problem among the explanatory variables.

Table 15. Multicollinearity test.

\begin{tabular}{lll}
\hline Model & Tolerance & VIF \\
\hline Age & .702 & 1.424 \\
Land & .929 & 1.077 \\
\hline
\end{tabular}

The figure 2 shows that the residual plots do not have any systematic pattern. It means that the data do not have heteroscedasticity problem.

\section{Dependent Variable: Total Income}

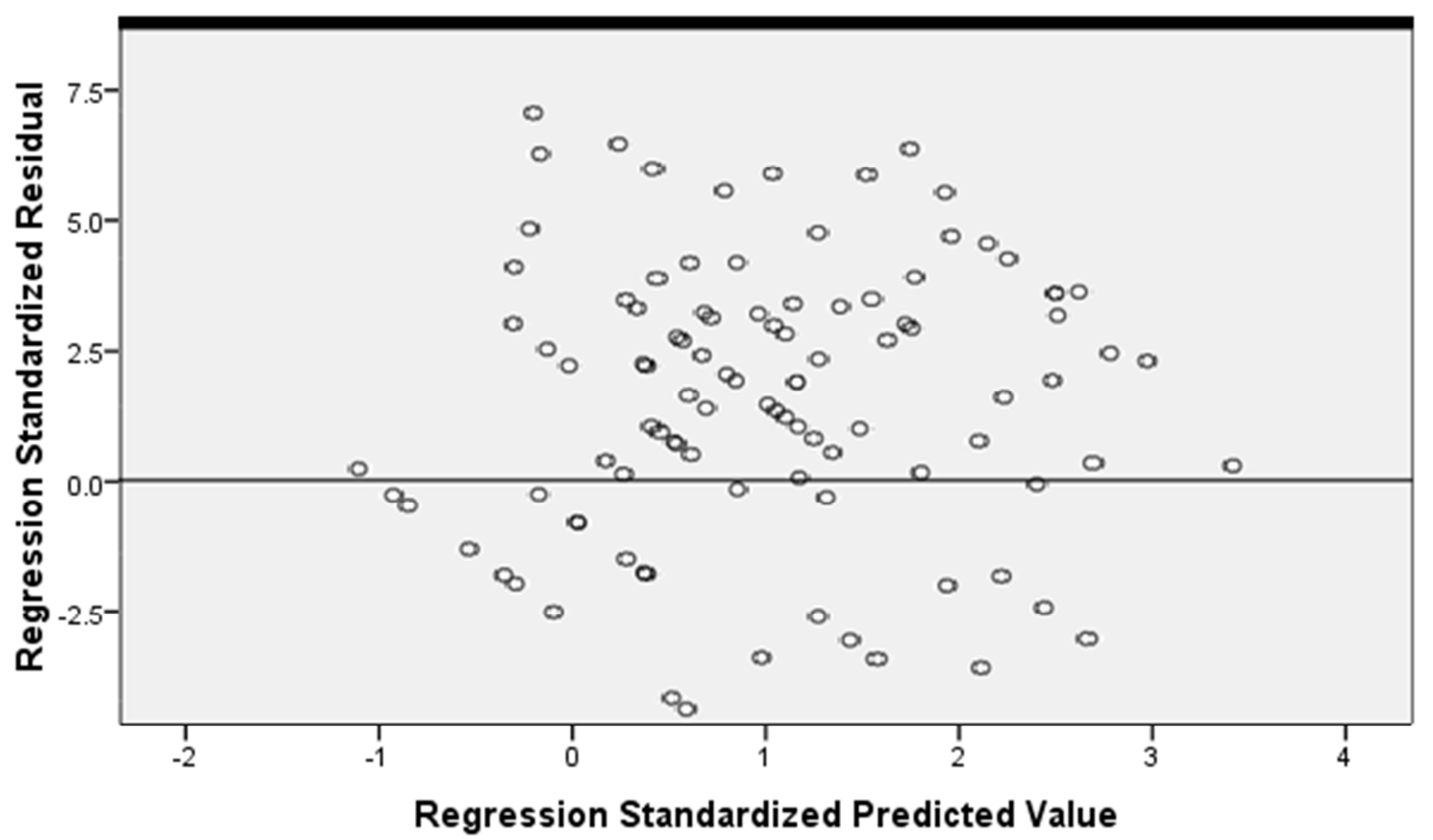

Figure 2. Test for homoscedasticity in data.

Table 16 shows that the value of coefficient of determination $\left(\mathrm{R}^{2}\right)$ is. 732 . It means that 73.2 percent of the variation in income of the borrowers (dependent variable) can be explained by the independent variables included in the model. 
Table 16. Model summary.

\begin{tabular}{ll}
\hline $\mathbf{R}$ & $\mathbf{R}$ Square \\
\hline .821 & .732 \\
\hline
\end{tabular}

ANOVA table shows that the F statistic is highly significant. It means that the independent variables are jointly significant to explain the dependant variable.

Table 17. ANOVA.

\begin{tabular}{llllll}
\hline Model & Sum of Squares & df & Mean Square & F & Sig. \\
\hline Regression & $8.543 \mathrm{E} 11$ & 5 & $1.709 \mathrm{E} 11$ & 19.000 \\
\hline Residual & $1.817 \mathrm{E} 12$ & 202 & $8.993 \mathrm{E} 9$ & & \\
Total & $2.671 \mathrm{E} 12$ & 207 & & & \\
\hline
\end{tabular}

It is found (Table 18) that coefficient for education is. 077 which is significant at $2.1 \%$ level. It means that if the borrowers are educated rather than uneducated, income of borrowers increases by $7.7 \%$ remaining other variables constant.

The coefficient for land is. 318 which is highly significant. It means that if amount of land increases by 1 unit, income of borrowers increases by $31.8 \%$ remaining other variables constant.

Table 18. Coefficients (dependant variable: income).

\begin{tabular}{llll}
\hline Model & Coefficients & t & Sig. \\
\hline Age & .086 & 1.239 & .217 \\
Education & .077 & 2.450 & .021 \\
Land & .318 & 5.278 & .000 \\
Borrowing from single source & - & 6.233 & .000 \\
Borrowing from two sources & .210 & 7.355 & .000 \\
Borrowing from more than two sources & .251 & 10.112 & .000 \\
\hline
\end{tabular}

Overall borrowing from different number of sources is highly significant. If borrowers borrow from two sources rather than single source, income of the borrowers increases by $21 \%$. If borrowers borrow from more than two sources rather than single source, income of the borrowers increases by $25.1 \%$. The results indicate that the more the borrowing, the more the income. It may be explained in the way that borrowers should be lent bigger amount to earn more.

\section{Conclusion and Recommendation}

Borrowers borrow from multiple sources due to unavailability of sufficient amount of credit from one source. Borrowers' living expenses on food, clothing, quality of shelter, level of health care show that the borrowers who borrow from single source are leading better lives than those who borrow from multiple sources. Analysis shows that there is no significant difference in gross income of the borrowers borrowing from different number of sources. But, in case of living expenses, savings and amount of non-land assets, there is significant difference between the groups of borrowers borrowing from single source and multiple sources. Borrowers who borrow from single source spend more for quality life than those who borrow from multiple sources. Since the borrowers who borrow from multiple sources are to pay a larger amount of their income in their installments and they are to bear larger transaction cost, they can save less in spite of making less expense on quality of life. The borrowers borrowing from single source have significantly higher amount of savings and non-land assets than those who borrow from multiple sources.

The study also shows that borrowers' education, amount of land and number of borrowing sources are significant factors of income. If borrowers borrow from two sources rather than single source, income of the borrowers increases by $21 \%$. If borrowers borrow from more than two sources rather than single source, income of the borrowers increases by $25.1 \%$. The results indicate that the more the borrowing, the more the income. It may be explained in the way that borrowing from multiple sources provides a bigger combined loan which generates more income. It appears that amount of loan from single source should be increased to improve the condition of borrowers.

Policy makers should take necessary steps to make policies so that the borrowers can get sufficient amount of loan from one source and they are encouraged to avoid loan from multiple sources which impose higher level of loan transaction costs \& repayment burden.

\section{Acknowledgements}

The research is funded by Institute of Research and Training (IRT), Southeast University, Dhaka, Bangladesh.

\section{References}

[1] Husain, S., Mahmud, K. T., \& Shihab, M. A. (2015). Small Credit for Big Opportunities: A Case of BRAC's Agribusiness Program in Bangladesh. International Journal of Economics and Finance, 8 (1), 7-14. DOI: 10.5539/ijef.v8n1p7.

[2] Mahmud, K. T., Parvez, A., Alom, K., Wahid, I. S., \& Hassan, M. K. (2017). Does Microcredit Really Bring Hope to the Female Borrowers in Bangladesh? Evidence from the Agribusiness Program of BRAC. Journal of Poverty, 21 (5), 434-453. DOI: 10.1080/10875549.2017.1348421.

[3] Presbitero, A. F., \& Rabellotti, R. (2014). Geographical distance and moral hazard in microcredit: Evidence from Colombia. Journal of International Development, 26, 91-108. doi: 10.1002/jid.2901.

[4] Mallick, D. (2012). Microfinance and moneylender interest rate: Evidence from Bangladesh. World Development, 40 (6), 1181-1189. doi: 10.1016/j.worlddev.2011.12.011. 
[5] Coleman, B. E. (2006). Microfinance in northeast Thailand: Who benefits and how much? World Development, 34 (9), 1612-1638. doi: 10.1016/j.worlddev.2006.01.006.

[6] Riedinger, J. M. (1994). Innovation in rural finance: Indonesia's Badan Kredit Kecamatan program. World Development, 22 (3), 301-313. doi: 10.1016/0305-750X (94) 90123-6.

[7] Coleman, B. E. (1999). The impact of group lending in northeast Thailand. Journal of Development Economics, 60 (1), 105-141. doi: 10.1016/S0304-3878 (99) 00038-3.

[8] Godquin, M. (2004). Microfinance repayment performance in Bangladesh: How to improve the allocation of loans by MFIs. World Development, 32 (11), 1909-1926. doi: 10.1016/j. worlddev.2004.05.011.

[9] Imai, K. S., Arun, T., \& Annim, S. K. (2010). Microfinance and household poverty reduction: New evidence from India. World Development, 38 (12), 1760-1774. doi: 10.1016/j. worlddev.2010.04.006.

[10] Dowla, A., \& Alamgir, D. (2003). From microcredit to microfinance: Evolution of savings products by MFIs in Bangladesh. Journal of International Development, 15, 969 988. doi: 10.1002/ (ISSN) 1099-1328.

[11] Garikipati, S. (2008). The impact of lending to women on household vulnerability and women's empowerment: Evidence from India. World Development, 36 (12), 2620 2642. doi: 10.1016/j.worlddev.2007.11.008.

[12] Dixon, R., Ritchie, J., \& Siwale, J. (2007). Loan officers and loan 'delinquency' in microfinance: A Zambian case. Accounting Forum, 31, 47-71. doi: 10.1016/j.accfor.2006.11.005.

[13] Bangladesh Bureau of Statistics, 2017.

[14] Kabeer, N. (2001). Conflicts over credit: Re-evaluating the empowerment potential of loans to women in rural Bangladesh. World Development, 29 (1), 63-84. http://dx.doi.org/10.1016/S0305-750X (00) 00081-4.

[15] Goetz, A. M., \&Gupta, R. S. (1996). Who takes the credit? gender, power, and control over loan use in rural creditprogrammes in Bangladesh. World Development, 24 (1), 45-63. http://dx.doi.org/10.1016/0305-750X (95) 00124-U.

[16] Parveen, S. (2008). Access of rural women to productive resources in Bangladesh: A pillar for promoting their empowerment international. Journal of Rural Studies, 15 (1), $1-8$.

[17] Mahmud, K. T., Hassan, M. K., Alam, M. F., Sohag, K., \& Rafiq, F. (2014). Opinion of the zakat recipients on their food security: a case study on Bangladesh. International Journal of Islamic and Middle Eastern Finance and Management, 7 (3), 333-345.

[18] Islam, M. S. (2014a). Role of Grameen Bank's microcredit in employment and empowerment of rural borrower-women in Bogra district. Southeast University Journal of Arts and Social Sciences, 1 (1), 60-74.

[19] Hossain, M. S., Wahid, I. S., Mahmud, K. T., Hossain, A. K., \& Taslim, T. (2013). Can small credit bring hope? A case study on the agribusiness program of BRAC in Bangladesh.
The Global Journal of Finance and Economics, 10 (2), $205-$ 214.

[20] Mahmud, K. T., Parvez, A., Hilton, D., Kabir, G. M. S., \&Wahid, I. S. (2014). The role of training in reducing poverty: The case of agricultural workers receiving microcredit in Bangladesh. International Journal of Training and $\begin{array}{llll}\text { Development, } & 18 & \text { (4), }\end{array}$ http://dx.doi.org/10.1111/ijtd.12039.

[21] Islam, M. S. (2014b). Impact of Grameen Bank's micro credit program on the living standard of rural women: A study of Bogra district. Development Compilation, 10 (02), 95-108.

[22] Mpogole, H., Mwaungulu, I., Mlasu, S., \& Lubawa, G. (2012). Multiple borrowing and loan repayment: a study of microfinance clients at Iringa, Tanzania. Global Journal of Management and Business Research, 12 (4), 96-102.

[23] Afroze, T., Rahman, S. M. T., \& Yousuf, S. (2014). Multiple borrowing through microcredit and its impact on loan repayment: study in Bangladesh. Research Journal of Finance and Accounting, 5 (21), 107-119.

[24] Deutsche Bank (2010). Retrieved from http://www.db.com.

[25] Diaz, J. N., Estoesta, J., Ledesma, J. M., Meneses, J. M. I., \& Onesa, L. G. (2011). Multiple Borrowing in the Philippines. MicroSave- Market-led solutions for financial services, Manila.

[26] Vogelgesang, U. (2003). Microfinance in times of crisis: the effects of competition, rising indebtedness, and economic crisis on repayment behavior. World Development, 31 (12), $2085-2114$.

[27] Chaudhury, I. A., \& Matin, I. (2002). Dimensions and dynamics of microfinance membership overlap - a micro study from Bangladesh. Small Enterprise Development, 13 (2), 46-55.

[28] Johnson, S. (2004). The dynamics of competition in Karatina's financial markets: assessing the impact of microfinance in Kenya. Imp-Act Working Paper 9, Institute for Development Studies, Brighton, Sussex, England.

[29] Krishnaswamy, K. (2007). Competition and Multiple Borrowing in the Indian Microfinance Sector. Working Paper, Centre for Micro Finance, Institute for Financial Management and Research, New Delhi, India.

[30] Khalily, M. A. B. (2011). Multiple Memberships (overlapping) in Micro Credit Market of Bangladesh. Working Paper, Institute of Microfinance, Bangladesh.

[31] Mukherjee, S. (2010). Multiple borrowing and competition: impact on credit quality. IFMR Capital, Chennai, India.

[32] Khalily, M. A. B., Faridi, R., \& Saeed, F. (2016). Does Overlapping Borrowing in Micro Credit Market Contribute to Over-Indebtedness in Bangladesh? Working Paper, Institute of Microfinance, Bangladesh.

[33] Krejcie, R. V., \& Morgan, D. W. (1970). Determining sample size for research activities. Educational and Psychological Measurement, 30 (2), 607-610. 